



\section{Nordiska rättsliga myndig- heter och det straffrättsliga samarbetet i EU}

Hans Frennered

TemaNord 2010:523 


\section{Nordiska rättsliga myndigheter och det straffrättsliga samarbetet I EU}

TemaNord 2010:523

(C) Nordiska ministerrådet, Köpenhamn 2010

ISBN 978-92-893-2053-5

Tryck: Kailow Express ApS

Upplaga: 280

Tryckt på miljövänligt papper som uppfyller kraven i den nordiska miljösvanemärkningen. Publikationen kan beställas på www.norden.org/order. Fler publikationer på www.norden.org/publikationer

Printed in Denmark

\section{Nordiska ministerrådet}

Store Strandstræde 18

DK-1255 Köpenhamn K

Telefon (+45) 33960200

Fax (+45) 33960202

\section{Nordiska rådet}

Store Strandstræde 18

DK-1255 Köpenhamn K

Telefon (+45) 33960400

Fax (+45) 33111870

www.norden.org

\section{Det nordiska samarbetet}

Det nordiska samarbetet är ett av världens mest omfattande regionala samarbeten. Det omfattar Danmark, Finland, Island, Norge och Sverige samt de självstyrande områdena Färöarna, Grönland och Åland.

Det nordiska samarbetet är politiskt, ekonomiskt och kulturellt förankrat och är en viktig partner i europeiskt och internationellt samarbete. Den nordiska gemenskapen arbetar för ett starkt Norden i ett starkt Europa.

Det nordiska samarbetet vill styrka nordiska och regionala intressen och värderingar i en global omvärld. Gemensamma värderingar länderna emellan bidrar till att stärka Nordens ställning som 


\section{Innehåll}

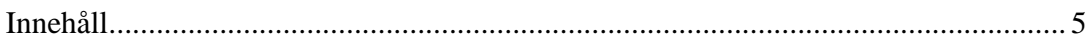

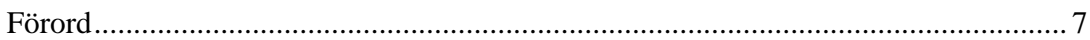

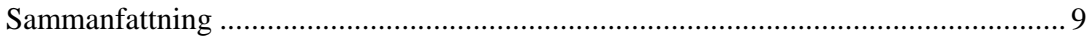

1. Nordiska rättsliga myndigheter i det straffrättsliga samarbetet i EU ...................... 11

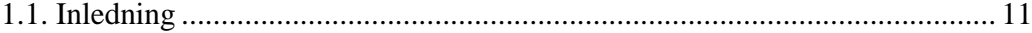

1.2. Förvaltningsmyndigheternas förhållande till statsmakterna ......................... 13

1.3. Förvaltningsmyndigheterna är regelstyrda .............................................. 16

1.4. Beslut av förvaltningsmyndigheterna kan överklagas till allmän

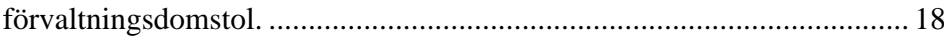

1.5. Tjänstemännens villkor samt insyn i och kontroll av förvaltningen ............... 21

1.6. Särskilt om behöriga myndigheter i rambesluten ........................................... 25

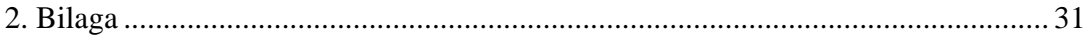

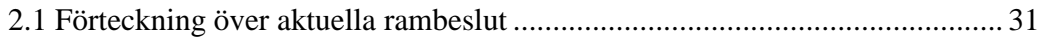





\section{Förord}

I januari 2009 uppdrog Nordiska rådets ämbetsmannakommitté för lagsamarbete åt en sakkunnig att ta fram en sakligt grundad beskrivning av den nordiska ämbetsmannamodellen och myndighetsstrukturen i de nordiska länderna.

Bakgrunden var att de nordiska länderna i det straffrättsliga samarbetet i Europeiska unionen ofta haft svårt att få förståelse hos övriga länder för sin uppfattning att också andra rättsliga myndigheter än domstolar och åklagare skall kunna vara utfärdande och verkställande myndigheter i ett samarbete som baseras på principen om ömsesidigt erkännande av domar och beslut.

Till sakkunnig utsågs hovrättslagmannen Hans Frennered, Hovrätten för Västra Sverige, Göteborg, och till sekreterare juris doktor Ingrid Helmius, Juridiska fakulteten vid Uppsala universitet. Den sakkunnige har samrått med en referensgrupp bestående av en ledamot från vart och ett av övriga nordiska länder (utom Island som valde att inte ha någon ledamot i referensgruppen). 



\section{Sammanfattning}

De nordiska länderna utgör sedan länge en kulturell gemenskap. Likheten länderna emellan i fråga om samhälleliga värderingar och politisk kultur brukar ofta sammanfattas med begreppet den nordiska modellen. Men även om likheterna är många så finns också skillnader. En sådan rör förvaltningsmyndigheternas förhållande till regeringsmakten.

Utgångspunkten i alla nordiska länder är att den statliga förvaltningen, det vill säga myndigheter och tjänstemän liksom regering och departement, i sin myndighetsutövning skall följa vissa grundläggande förvaltningsrättsliga principer. Till dessa hör legalitetsprincipen samt principerna om likabehandling, objektivitet och proportionalitet. Dessa principer för förvaltningen (les principes Généreaux du droit publique) är antingen föreskrivna i grundlag eller vanlig lag eller tillämpas genom långvarig och fast praxis.

Att tjänstemännen i sin myndighetsutövning skall vara opartiska och ojäviga är föreskrivet i bestämmelser i lag som överensstämmer med motsvarande bestämmelser för domare.

Förvaltningsbeslut kan enligt bestämmelser i lag överklagas, antingen till allmän domstol eller förvaltningsdomstol eller till annat domstolsliknande organ.

I fråga om anställningstrygghet och ansvar för fel i tjänsten är reglerna likartade länderna emellan. Sålunda får ingen skiljas från sin anställning utan sakliga skäl och i samtliga länders strafflagstiftning finns regler om straffansvar för fel begångna i tjänsten samt för tagande av och givande av muta. På samma sätt överensstämmer ländernas regler om det allmännas skadeståndsansvar för skador föranledda av fel och försummelser i myndighetsutövning.

Tjänstemännen vid de statliga myndigheterna står, utöver tillsyn av den egna myndigheten och de brottsbekämpande myndigheterna, enligt 
lag även under tillsyn av särskilda ombudsmän som har till uppgift att vaka över att de som utövar offentlig verksamhet efterlever lagar och förordningar samt även i övrigt fullgör sina skyldigheter.

Allmänhetens möjligheter till insyn och kontroll av den offentliga förvaltningen främjas i hög grad genom att allmänna handlingar som finns hos myndigheterna som huvudregel är offentliga och att undantag från denna regel, det vill säga sekretess, endast kan ske med stöd av föreskrifter i lag.

På grund av historiskt arv är myndigheterna i Sverige och Finland i konstitutionellt avseende självständiga i förhållande till regeringen medan Danmark, Norge och Island däremot, liksom många andra europeiska länder, har vad som brukar kallas ministerstyre. Detta innebär att det är den ansvarige ministern som är ytterst ansvarig för beslut av underordnade myndigheter. Ministern är självfallet bunden av lag och kan ställas till rättsligt ansvar för felaktigheter i sin ämbetsutövning. Även när tillämpningen av en lagstiftning i och för sig ger utrymme för en betydande skönsmässighet gäller sålunda också för en minister att han eller hon ska efterleva de grundläggande principerna om likabehandling, objektivitet och proportionalitet. Dessutom finns möjlighet för den enskilde att efter överklagande få även ett ministerbeslut prövat i domstol. 


\section{Nordiska rättsliga myndigheter i det straffrättsliga samarbetet i EU}

\subsection{Inledning}

I Europeiska Unionens rättsakter på området för samarbete i rättsliga och inrikes frågor används ofta begreppet rättslig myndighet. Särskilt har så varit fallet efter det att Europeiska rådet vid sitt möte i Tammerfors i oktober 1999 antog ett åtgärdsprogram för att genomföra principen om ömsesidigt erkännande av domar i brottmål. Ett tidigt exempel där begreppet används är rambeslutet av den 13 juni 2002 om en europeisk arresteringsorder och överlämnande mellan medlemsstaterna, i vilket förekommer såväl utfärdande som verkställande rättslig myndighet. Klart står numera att med rättslig myndighet inte enbart avses domstolar i egentlig mening och åklagare utan även andra myndigheter. I rambeslutet av den 18 december 2008 om en europeisk bevisinhämtningsorder anges exempelvis att en sådan order endast bör kunna utfärdas av domare, domstolar, undersökningsdomare, allmänna åklagare och vissa andra rättsliga myndigheter som utses av medlemsstaterna. Än tydligare framgår det i rambeslutet av den 27 november 2008 om ömsesidigt erkännande av domar och övervakningsbeslut, där det föreskrivs att medlemsländerna får utse andra myndigheter än rättsliga myndigheter under förutsättning att dessa är behöriga att fatta motsvarande beslut enligt landets nationella regler. Samma formulering används i ett rambeslut om ömsesidigt erkännande av beslut om övervakningsåtgärder för brottsmisstänkta (artikel 6.2), dock med det undantaget (artikel 6.3) att en arresteringsorder (enligt artikel 18.1) skall utfärdas av en rättslig myndighet. 
Inom ramen för det straffrättsliga samarbetet i EU har Danmark, Finland och Sverige ofta med kraft hävdat att också andra rättsliga myndigheter än domstolar och - i förekommande fall - åklagare skall kunna vara utfärdande och verkställande myndighet i ett samarbete som baseras på principen om ömsesidigt erkännande av domar och beslut. Det har dock allt som oftast visat sig vara svårt att i dessa sammanhang få förståelse och gehör för denna hållning, särskilt när det gäller utfärdande myndighet. Ett exempel på detta är att vid rådets utvärdering av tillämpningen i Sverige av rambeslutet om en europeisk arresteringsorder det framfördes synpunkter från sina håll på att Sverige, som utfärdande rättslig myndighet i fråga om utfärdande av en arresteringsorder för verkställighet i Sverige av en frihetsberövande påföljd, anförtrott denna uppgift på en polismyndighet (Rikspolisstyrelsen). Detta ansåg kritikerna inte stämma överens med att en arresteringsorder enligt rambeslutet (artikel 1:1) är ett rättsligt avgörande.

Denna tveksamhet till de nordiska ländernas inställning synes ha sin grund i en uppfattning att det endast är domstolar i egentlig mening och åklagare som lever upp till vad som från främst rättssäkerhetssynpunkt bör krävas i fråga om bland annat regelstyrning, oavhängighet, opartiskhet och kompetens. Detta kan i sin tur ha sin grund i otillräcklig kunskap om att de nordiska ländernas myndighetsstrukturer och tjänstemannatraditioner är speciella och skiljer sig från andra medlemsländers motsvarigheter. En bidragande anledning kan i värsta fall också vara en bristande vilja att förstå och respektera att EU:s medlemsländer av historiska, konstitutionella och kulturella orsaker har i viss mån olika tillvägagångssätt när det gäller att trygga rättssäkerheten och uppfylla de krav som EUsamarbetet och även Europakonventionen ställer. Det förhållandet att den nordiska rättstraditionen inte helt överensstämmer med den kontinentala betyder naturligtvis ingalunda att den skulle vara sämre skickad att tillgodose medborgarnas grundläggande fri- och rättigheter.

I det följande beskrivs de övergripande principer som gäller i Danmark, Finland, Sverige Norge och Island för statliga myndigheters verksamhet och tjänstemän.

Avslutningsvis (i bilagan) redovisas så långt möjligt vilka myndigheter i Sverige, Finland och Danmark som är aktuella som behöriga myndigheter enligt rambeslut som har antagits eller som förväntas bli antagna inom den närmaste framtiden. För Norges och Islands del synes utgångs- 
punkten vara att det är det för frågan ansvariga departementet - vanligen Justisdepartementet - som kommer att vara behörig myndighet enligt rambesluten.

\subsection{Förvaltningsmyndigheternas förhållande till statsmakterna}

\subsubsection{Sverige}

Det elfte kapitlet i regeringsformen (RF) har rubriken Rättskipning och förvaltning. Där finns de grundläggande bestämmelserna om domstolarnas och myndigheternas konstitutionella ställning. I 11 kap. 7 § föreskrivs att ingen myndighet, inte heller riksdagen, får bestämma hur en myndighet skall besluta i ett ärende som rör myndighetsutövning mot enskild eller som rör tillämpning av lag. Statsmakterna har alltså vad gäller sådan myndighetsutövning och rättstillämpning inte befogenhet att påverka myndigheterna annat än genom lagstiftning. Bestämmelsen överensstämmer till sitt innehåll helt med motsvarande bestämmelse för domstolarna i 11 kap. 2 §. Enligt 6 § lyder myndigheterna under regeringen. I Sverige har en enskild minister inte någon befälsrätt över en myndighet, och en föreskrift från regeringen skall riktas inte till tjänstemännen utan till myndigheten som sådan. Materiella regler stiftas genom lag i riksdagen och regler om myndigheternas organisation och verksamhet genom sådan lag eller förordning beslutad av regeringen. Myndigheterna i Sverige, liksom även i Finland, är således självständiga i förhållande till regeringen.

\subsubsection{Finland}

I Finlands grundlag (GL) garanteras förvaltningsmyndigheterna självständighet i förhållande till regeringen. Enligt $21 \S$, med underrubriken Rättsskydd, har var och en rätt att på behörigt sätt och utan ogrundat dröjsmål få sin sak behandlad av en domstol eller någon annan myndighet som är behörig enligt lag samt att få ett beslut som gäller hans eller hennes rättigheter och skyldigheter behandlat vid domstol eller något annat oavhängigt rättskipningsorgan. I bestämmelsen föreskrivs vidare att of- 
fentligheten vid handläggningen, rätten att bli hörd, rätten att få motiverade beslut och rätten att söka ändring samt andra garantier för en rättvis rättegång och god förvaltning skall tryggas genom lagstiftning. Som exempel kan nämnas 1 § i lagen om allmänna åklagare (11.3.1997/199) där det framgår att åklagaren utövar en självständig åtalsprövningsrätt i sina ärenden.

\subsubsection{Danmark}

De grundläggande reglerna om maktdelning finns i Grundloven (Grl) § 3, där det föreskrivs att den lagstiftande makten är hos kungen (det vill säga regeringen) och folketinget i förening och att den utövande makten är hos regeringen. Detta innebär att det i enskilda fall är förvaltningen som fattar beslut och att den lagstiftande makten inte i allmänhet har möjlighet att fatta sådana beslut (utom när grundlagen medger det, till exempel angående danskt medborgarskap för utlänningar).

När det gäller förvaltningsbeslut tillämpas i Danmark (liksom i Norge och i Island) sedan länge vad som brukar kallas ministerstyre. Det innebär att en minister kan besluta i alla ärenden inom sitt ansvarsområde. Alla förvaltningsbeslut fattas på ministerns vägnar och ministern kan när som helst instruera underlydande eller själv ta över behandlingen av ett ärende. Men även ministern är bunden av lag och kan ställas till ansvar för felaktig ämbetsutövning.

På vissa områden finns särskild lagstiftning om oavhängiga förvaltningsorgan. Detta gäller till exempel Flygtningenævnet, som är en förvaltningsmyndighet, som beslutar bland annat i frågor om utlänningars rätt att uppehålla sig i Danmark. Om det inte är särskilt angivet i lag, kan ministern inte instruera sådana nämnder om vilka beslut de skall fatta och inte heller ompröva deras beslut.

\subsubsection{Norge}

Enligt Grunnloven (Grl) § 3 är den utövande makten hos kungen, vilket innebär att det är regeringen som styr förvaltningen. Att regeringen styr innebär för det första att det är regeringen som anställer och avskedar tjänstemän på statsförvaltningens nyckelposter samt för det andra att regeringen som regel kan ge bindande instruktioner till tjänstemännen. 
Instruktionerna kan vara av generell art och kan avse vilka uppgifter de enskilda tjänstemännen skall ha, vilka upplysningar som skall inhämtas för att fatta beslut och vilka hänsyn som skall beaktas vid beslutsfattandet. Men det kan också vara fråga om en speciell instruktion för hur ett bestämt ärende skall avgöras. För det tredje innebär det att regeringen har rätt att ompröva beslut som de underordnade myndigheterna har fattat utom när beslutet inneburit en oangriplig rätt för någon.

Liksom i Danmark har den ansvarige ministern (och på dennes vägnar departementet) rätt att kontrollera och instruera underliggande förvaltningsorgan och rätt att ompröva beslut i enskilda ärenden. Det är departementen som direkt utövar den verkställande makten. Det skulle dock strida mot grundlagens system om ett departement fick rätt att driva sin vilja igenom i strid med regeringens.

Det är naturligtvis bara en liten del av de enskilda förvaltningsärendena som regeringen själv kan handlägga. Det flesta ärendena måste överlåtas till offentliga tjänstemän på högre och lägre nivå i departementen och direktoraten. De norska direktoraten fattar beslut i eget namn, det vill säga inte, som i Danmark, på ministerns vägnar.

Om lagstiftaren vill lägga en viss befogenhet på ett organ som är oavhängigt i förhållande till regeringen, kan den göra det under förutsättning att det inte strider mot Grl. Uppgifter som Grl speciellt lägger på regeringen - regeringens så kallade prerogativ - kan således inta fråntas regeringen av lagstiftaren. Inte heller kan sådana uppgifter flyttas över till myndigheter som regeringen inte styr. När Grl $\S 20$ lägger rätten att benåda hos regeringen kan inte lagstiftaren lägga över denna befogenhet till en i förhållande till regeringen oavhängig myndighet. Utanför det område som prerogativet omfattar är förhållandet annorlunda. Här kan lagstiftaren överlämna makten att utöva myndighet till organ som inte utnämns av regeringen och som därmed fattar beslut helt oavhängigt av denna.

\subsubsection{Island}

De grundläggande reglerna om maktdelning finns i stjórnarskráin (grundlagen) $\S 2$, där det föreskrivs att den lagstiftande makten finns hos presidenten (det vill säga regeringen) och Alltinget i förening och att regeringen har den utövande makten. Detta innebär att det i enskilda fall är för- 
valtningen som fattar beslut och att den lagstiftande makten inte i allmänhet har möjlighet att fatta sådana beslut.

När det gäller förvaltningsbeslut tillämpas i övrigt i Island (liksom i Norge och Danmark) vad som brukar kallas ministerstyre. Det innebär att en minister kan besluta i alla ärenden inom sitt ansvarsområde. Liksom i Danmark fattas alla förvaltningsbeslut på ministerns vägnar och ministern kan när som helst instruera underlydande eller själv ta över behandlingen av ett ärende. Men även ministern är bunden av lag och kan ställas till ansvar för felaktig ämbetsutövning.

På vissa områden finns särskild lagstiftning om oavhängiga förvaltningsorgan. Om det inte är särskilt angivet i lag, kan ministern inte instruera sådana förvaltningsorgan om vilka beslut de skall fatta och inte heller ompröva deras beslut.

\subsection{Förvaltningsmyndigheterna är regelstyrda}

\subsubsection{Sverige}

Enligt 1 kap. $1 \S$ RF utövas den offentliga makten under lagarna. Makt skall med andra ord utövas i enlighet med vad som brukar benämnas legalitetsprincipen. Den självständighet som enligt regeringsformen har tillförsäkrats myndigheterna vid myndighetsutövning och rättstillämpning i enskilda fall är således en självständighet under lagarna och inte en självständighet att oberoende av lagarna handla efter eget gottfinnande.

Även de så kallade likhets- och objektivitetsprinciperna är grundlagsfästa (1 kap. $9 \S \mathrm{RF}$ ). De innebär att ett myndighetsbeslut måste vara resultatet av ett övervägande i fråga om vad som i det enskilda fallet är det objektivt riktiga. En myndighet får inte grunda sina avgöranden på andra hänsyn än sådana som lagligen får beaktas vid prövningen av ett ärende.

Myndigheterna skall iaktta proportionalitetsprincipen. Den innebär att utövning av makt inte får gå utöver vad som är nödvändigt med hänsyn till ändamålet och att den åtgärd skall väljas som innebär det lindrigaste ingreppet för den enskilde samt att den åtgärd som vidtas måste stå i rimlig proportion till vikten av vad som skall uppnås med åtgärden. Principen är fullt erkänd i svensk rättspraxis och kommer till uttryck på flera håll i 
lagstiftningen, bland annat i 2 kap. 12 § RF. Europakonventionen om mänskliga rättigheter är införlivad i svensk rätt genom lag.

För samtliga myndigheter finns det bestämmelser i lag om att en tjänsteman vid en myndighet inte får fatta beslut om det föreligger jäv. För tjänstemän i allmänhet finns dessa bestämmelser i förvaltningslagen och för tjänstemän vid de brottsutredande myndigheterna och Kronofogdemyndigheten i rättegångsbalken. Detta innebär att bestämmelserna om jäv för tjänstemän vid myndigheter är desamma som för domare.

Om en myndighet inte har iakttagit reglerna om saklighet och opartiskhet, har den enskilde efter överklagande möjlighet att få ett myndighetsbeslut upphävt av domstol.

Beslut av en myndighet får som huvudregel överklagas till domstol. Förvaltningslagen innehåller en allmän bestämmelse om att beslut av en myndighet överklagas till allmän förvaltningsdomstol. Beslut som har fattats av myndigheter med uppgift att verkställa brottspåföljder får överklagas till allmän domstol eller allmän förvaltningsdomstol. För myndigheter med brottsutredande uppgifter finns bestämmelser om användningen av tvångsmedel. För denna typ av ärenden finns också bestämmelser om överprövning i domstol av åklagares beslut och om överklagande av domstols beslut.

\subsubsection{Finland}

Flera av de grundläggande principerna för offentlig maktutövning är fastlagda i GL. Vad gäller legalitetsprincipen stadgas i $1 \S$ GL att all utövning av offentlig makt skall bygga på lag och att lag noggrant skall iakttas i all offentlig verksamhet. I 2 kap. GL, som har rubriken Grundläggande fri- och rättigheter, lagfästs principen om allas likhet inför lagen (6 §) och att det allmänna skall se till att de grundläggande fri- och rättigheterna och de mänskliga rättigheterna tillgodoses (22 §). Europakonventionen om mänskliga rättigheter är införlivad i finsk rätt genom lag.

Bestämmelser om jäv finns för tjänstemän i allmänhet i förvaltningslagen, för åklagare i lagen om allmänna åklagare, för poliser och andra med brottsutredande uppgifter i förundersökningslagen samt för utsökningsmän i utsökningslagen. 


\subsection{Beslut av förvaltningsmyndigheterna kan överklagas till allmän förvaltningsdomstol.}

\subsubsection{Danmark}

I den mån det följer direkt av lag hur förvaltningen skall fatta beslut $\mathrm{i}$ enskilda fall sätter de grundläggande rättsgrundsatserna gränserna för förvaltningens verksamhet. Dessa grundsatser hämtar inte sin giltighet från lagstiftning i folketinget. De flesta har i stället vuxit fram i praxis. Karaktäristiskt för rättsgrundsatserna är att de gäller större delen av förvaltningen och inte, som fallet är med lagstiftning, endast bestämda, begränsade rättsområden. Det är till och med så att de allmänna förvaltningsrättsliga rättsgrundsatserna i stort har samma innehåll som les principes Généreaux du droit publique, av franskt ursprung, som har brett ut sig till att gälla större delen av Västeuropa.

När det gäller departement och styrelser/direktorat med flera som lyder under enskilda departement är varje minister i princip ytterst ansvarig för det område som faller inom departementets verksamhetsområde. Ministern (eller dennes ämbets- och tjänstemän) kan inte styras när det gäller hur en enskild fråga skall behandlas, men ministern är underkastad legalitetsprincipen.

Legalitetsprincipen innebär bland annat att förvaltningen måste utövas efter bemyndigande från lagstiftaren (lagstöd). Legalitetsprincipen garanterar, tillsammans med bland annat regler om utnämning och kontrollsystem, förvaltningsorganens oavhängighet. Förvaltningsorganens oavhängighet innebär att en myndighet inte kan fatta beslut som styrs av t.ex. politiska hänsyn eller intressen som inte har stöd i lag.

Bestämmelser om jäv (inhabilitet) finns i retsplejeloven och forvaltningsloven.

Danmark saknar förvaltningsdomstolar. Huvudregeln är i stället att förvaltningsbeslut kan överklagas till den ansvarige ministern. Slutligen finns alltid möjligheten att överklaga förvaltningsbeslut till allmän domstol (jfr Grl § 63). 


\subsubsection{Norge}

Något generellt uttryck har legalitetsprincipen inte fått i grundlagen. Principen är emellertid fastslagen på konstitutionell eller grundlagsnivå genom långvarig och stadig praxis. Det är inte sällan som domstolarna underkänner förvaltningsbeslut därför att de saknat stöd i lag. Förvaltningen i Norge är enligt legalitetsprincipen bunden av lagar och andra bestämmelser. Legalitetsprincipen innebär att offentliga myndigheter inte kan lägga sig i medborgarnas liv genom enskilda beslut utan att ha stöd för detta i lag. Detta gäller både rättsliga och faktiska ingrepp.

Ingrepp i enskilda rättigheter kräver alltså stöd i lag. Principen gäller inte bara gentemot enskilda individer, även om det är det centrala, utan även juridiska personer, exempelvis aktiebolag. Om det inte finns någon generell lagregel som ger stöd för ett avsett ingrepp, kräver legalitetsprincipen att det finns grund för ett sådant beslut i speciallagstiftning i det särskilda fallet.

Grundlagens krav på lagstöd skall vidare tolkas i överensstämmelse med de internationella människorättighetsförpliktelser som Norge har tagit på sig, exempelvis de som anges i Europakonventionen. För förvaltningen gäller också andra principer som skall förhindra att makten missbrukas. Hit hör principen om att inte ta ovidkommande hänsyn, objektivitetsprincipen och proportionalitetsprincipen.

Många förvaltningsbeslut är så strängt lagbundna att en förvaltningsmyndighet endast har att kontrollera att lagens villkor är uppfyllda. Ett exempel är reglerna om tillstånd att driva advokatverksamhet. Sådant tillstånd söks hos departementet och om villkoren är uppfyllda skall departementet bevilja ansökan. Departementet kan inte godkänna eller avslå en ansökan efter eget skön.

Även de grundläggande principerna om likabehandling och objektivitet tillämpas av norska myndigheter på grundval av lång och fast praxis. Detsamma gäller proportionalitetsprincipen som dock, när det gäller tvångsmedelsanvändning, också är föreskriven i lag (straffeprosessloven $\S 170 a)$.

Bestämmelser om jäv (ugildhet) finns bland annat i domstolsloven, forvaltningsloven och tvangsfullbyrdelseloven.

Förvaltningsmyndigheternas beslut är underkastade domstolsprövning, dock inte i alla avseenden. I Norge finns inga särskilda förvaltningsdomstolar utan det är de allmänna domstolarna som överprövar även 
förvaltningsbeslut. Om det gäller ett beslut av ett underordnat förvaltningsorgan, kan beslutet i allmänhet överklagas till överordnat organ. Ett förvaltningsorgan kan bestämma att den som vill väcka talan om lagligheten i ett förvaltningsbeslut eller om ersättning för ett sådant beslut först måste utnyttja den administrativa besvärsvägen.

Domstolen prövar om beslutet har stöd i lag, om lagen är tolkad på rätt sätt och om förvaltningen har utövat sin myndighet med beaktande av de nämnda principerna. Detta innebär att förvaltningen i vissa fall skönsmässigt kan välja hur ett ärende skall avgöras. Hur stort området för denna skönsmässiga bedömning är kommer an på huruvida förvaltningens myndighet är angiven i den aktuelle lagen. Typisk sett kan det vara så att förvaltningen kan ge dispens om vissa villkor är uppfyllda. Det innebär att förvaltningen kan välja mellan att ge eller inte ge dispens utan att domstolen kan överpröva detta val. I andra fall kan förvaltningen ha anledning att ge en dispens eller ett tillstånd på vissa villkor.

Domstolarnas prövningsrätt av förvaltningsbeslut går mycket längre än deras prövningsrätt av lag, och är politiskt mindre omstridd. Förvaltningsbeslut kan domstolen underkänna inte bara när de är grundlagsstridiga, utan också när de är olagliga. Däremot kan ett myndighetsbeslut som regel inte angripas med stöd av att förvaltningsorganet har tillämpat den makt lagen ger det, på uheldig eller uhensiktismessig måte.

I vissa länder, som i princip erkänner domstolarnas prövningsrätt av förvaltningsbeslut, har det gjorts större eller mindre undantag för avgöranden från de allra högsta statsorganen. Sådana undantag finns inte i Norge. Även ett regeringsbeslut som många av stortingets ledamöter står bakom, kan underkännas av domstol om det strider mot grundlag eller lag. Grundlag och lag står över regering och storting.

\subsubsection{Island}

Förvaltningen i Island är i enlighet med legalitetsprincipen bunden av lagar och andra bestämmelser. Något generellt stadgande har legalitetsprincipen inte fătt i grundlagen. Principen är emellertid fastslagen på konstitutionell nivå genom en långvarig och stabil praxis. Legalitetsprincipen innebär att offentliga myndigheter inte kan besluta om enskilda individers eller juridiska personers angelägenheter utan att ha stöd för detta i lag. Detta gäller både rättsliga och faktiska ingrepp. Legalitetsprin- 
cipen garanterar också förvaltningsorganens oavhängighet. Detta innebär att en myndighet inte kan fatta beslut som styrs av hänsyn eller intressen som inte har stöd i lag.

Bestämmelser om jäv finns i både civilprocesslagen och förvaltningslagen.

Island saknar förvaltningsdomstolar. Huvudregeln är i stället att förvaltningsbeslut kan överklagas till den ansvarige ministern. I undantagsfall kan förvaltningsbeslut enligt lag överklagas till särskilt förvaltningsorgan. Slutligen finns alltid möjligheten att överklaga förvaltningsbeslut till allmän domstol (jfr. grundlagen § 60). Domstolen kan underkänna ett förvaltningsbeslut som strider mot grundlag eller lag.

\subsection{Tjänstemännens villkor samt insyn i och kontroll av förvaltningen}

\subsubsection{Sverige}

För alla arbetstagare i Sverige gäller lagen om anställningsskydd. I den lagen föreskrivs att en arbetstagare, alltså även en tjänsteman vid en myndighet, får avskedas endast om tjänstemannen har grovt åsidosatt sina åligganden i tjänsten och att avskedanden skall begränsas till endast uppenbara fall av avsiktliga eller grovt vårdslösa förfaranden. För en uppsägning från myndighetens sida måste det finnas saklig grund, till exempel arbetsbrist, inkompetens eller frånvaro. Lagen om offentlig anställning innehåller särskilda regler om förhållandet mellan en tjänsteman och den statliga myndigheten som arbetsgivare. Enligt den lagen kan en myndighet meddela disciplinpåföljder i form av varning eller löneavdrag. För en sådan påföljd krävs att en tjänsteman uppsåtligen eller av oaktsamhet har åsidosatt sina skyldigheter i anställningen.

Enligt 20 kap. $1 \S$ brottsbalken skall den som uppsåtligen eller av oaktsamhet vid myndighetsutövning genom handling eller underlåtenhet åsidosätter vad som gäller för uppgiften dömas för tjänstefel eller - i allvarliga fall - för grovt tjänstefel. En tjänsteman som för sig själv eller för annan tar emot, låter sig utlovas eller begär en muta eller annan otillbörlig belöning för sin tjänsteutövning gör sig skyldig till mutbrott. Tagande av muta är, liksom bestickning, straffbara handlingar enligt 20 kap. $2 \S$ re- 
spektive 17 kap. $7 \S$ brottsbalken. Sverige har tillträtt samtliga internationella konventioner på området för åtgärder mot korruption.

Staten är enligt lag skyldig att betala skadestånd för personskada, sakskada eller ren förmögenhetsskada, som vållats genom fel eller försummelse vid myndighetsutövning i verksamhet som staten ansvarar för, och för skada på grund av att någon kränkts genom brott som innefattar ett angrepp mot dennes person, frihet, frid eller ära genom fel eller försummelse vid myndighetsutövning (3 kap. 2 § skadeståndslagen). Staten kan åläggas skadeståndsskyldighet också med direkt stöd av Europakonventionen.

I likhet med domare står tjänstemän vid de statliga myndigheterna, utöver tillsyn av den egna myndigheten och de brottsbekämpande myndigheterna, under tillsyn även av Riksdagens ombudsmän (Justitieombudsmannen, JO) som vakar över att lagar och andra författningar efterlevs. Tillsynen bedrivs genom prövning av klagomål från enskilda och genom inspektioner och andra undersökningar som JO företar. JO får som särskild åklagare väcka åtal mot tjänstemän som genom att åsidosätta vad som har ålegat dem i tjänsten har begått en brottslig gärning. I sådana fall tillämpas reglerna i rättegångsbalken om förundersökning och åtal. Även Justitiekanslern (JK), som är en regeringens myndighet, har till uppgift att ha tillsyn över att de som utövar offentlig verksamhet efterlever lagar och förordningar samt i övrigt fullgör sina skyldigheter. Också JK har rätt att väcka åtal mot domare och andra statliga tjänstemän.

I Sverige är den så kallade offentlighetsprincipen fastlagd i grundlag (3 kap. tryckfrihetsförordningen och 2 kap. yttrandefrihetsgrundlagen). Handlingar och uppgifter - inklusive bandupptagningar och datalagrad information - som finns hos en myndighet är därmed tillgängliga för alla och envar. Offentlighet är huvudregeln och sekretess är undantaget. Principen innebär att det alltid krävs stöd i lag för att en myndighet skall kunna vägra att lämna ut en uppgift eller en handling. Offentlighetsprincipen i förening med det likaledes (i 1 kap. $1 \S$ tryckfrihetsförordningen och 1 kap. $2 \S$ yttrandefrihetsgrundlagen) grundlagsfästa meddelarskyddet utgör viktiga beståndsdelar i allmänhetens möjligheter till insyn och kontroll av den offentliga verksamheten. Ett inslag i meddelarskyddet är att den som har tystnadsplikt inom vissa ramar har rätt att bryta tystnadsplikten då en uppgift lämnas till massmedia eller till en författare, om syftet är att uppgiften skall publiceras. 


\subsubsection{Finland}

En tjänsteman svarar enligt 118 § GL för att vidtagna ämbetsåtgärder är lagliga. Tjänstemannen har ansvar också för sådana beslut i ett kollegialt organ som tjänstemannen i egenskap av medlem av organet har biträtt.

Bestämmelser som gäller möjligheten att avsluta ett tjänsteförhållande finns i statstjänstemannalagen. Enligt 7 kap. $33 \S$ kan en tjänstemans tjänsteförhållande genast upplösas av myndigheten om tjänstemannen grovt bryter mot eller åsidosätter sin tjänsteplikt. En myndighet har enligt 7 kap. $25 \S$ därutöver rätt att säga upp en tjänsteman om ämbetsverket eller den enhet där tjänstemannen arbetar läggs ner, eller tjänstemannens uppgifter eller ämbetsverkets möjligheter att erbjuda honom uppgifter minskar väsentligen och inte bara tillfälligt. Myndigheten har dock inte rätt att säga upp en tjänsteman av dessa orsaker om tjänstemannen med hänsyn till sin yrkesskicklighet och förmåga skäligen kan omplaceras eller utbildas för nya uppgifter inom samma ämbetsverk eller om tjänsten överförs till ett annat ämbetsverk. Enligt 7 kap. 25 § får en myndighet inte säga upp ett tjänsteförhållande av något skäl som beror av tjänstemannen om inte skälet är synnerligen vägande.

Var och en som har lidit rättskränkning eller skada till följd av en lagstridig åtgärd eller försummelse av en tjänsteman eller någon som sköter ett offentligt uppdrag har enligt 118 § GL, enligt vad som närmare bestäms genom lag, rätt att yrka att denne döms till straff samt kräva skadestånd av det offentliga samfundet eller av tjänstemannen eller den som sköter det offentliga uppdraget.

Tagande av muta är kriminaliserat enligt 40 kap. 1-3 §§ strafflagen. En tjänsteman kan även dömas till avsättning, om brottet visar att han eller hon är uppenbart olämplig för sitt uppdrag. Den aktiva delen, givande av muta är likaledes kriminaliserad (16 kap. 13 § och 14 §).

Om en tjänsteman i syfte att bereda sig eller någon annan nytta eller orsaka olägenhet eller skada för någon annan 1) bryter mot sin tjänsteplikt enligt bestämmelser eller föreskrifter som skall iakttas i tjänsteutövning, när han eller hon deltar i beslutsfattande eller beredning av beslutsfattande eller utövar offentlig makt i sina andra tjänsteåligganden, eller 2) missbrukar sin ställning i förhållande till någon som står i direkt lydnadsförhållande till honom eller henne eller under hans eller hennes omedelbara tillsyn, skall tjänstemannen dömas för missbruk av tjänsteställning (40 kap. $7 \S$ och 8 §). Tjänstemannen kan, som har nämnts, vid de nu 
uppräknade brotten även dömas till avsättning, om brottet visar att han eller hon är uppenbart olämplig för sitt uppdrag. En tjänsteman som bryter mot eller åsidosätter sin tjänsteplikt kan enligt 6 kap. $24 \S$ statstjänstemannalagen ges en skriftlig varning.

Finland har undertecknat FN-konventionen mot korruption. Konventionen har införlivats genom lag. Finland har ratificerat även Europarådets straffrättsliga respektive civilrättsliga konvention om korruption.

Ett offentligt organ är enligt 3 kap. 2 § skadeståndslagen skyldigt att ersätta skada som förorsakats genom fel eller försummelse vid myndighetsutövning. Samma skadeståndsskyldighet åligger annat organ, som på grund av lag, förordning eller bemyndigande i lag handhar offentlig uppgift. Ansvar föreligger dock endast om de krav blivit åsidosatta som med hänsyn till verksamhetens art och ändamål skäligen kan ställas på fullgörandet av åtgärden eller uppgiften. Enligt 4 kap. 2 §skadeståndslagen är en tjänsteman enligt de grunder som nämnts ansvarig för den skada som han i sin tjänst vållar genom fel eller försummelse.

Justitieombudsmannen (JO) skall enligt 109 § GL övervaka att domstolarna och andra myndigheter samt tjänstemännen, offentligt anställda arbetstagare och också andra, när de sköter offentliga uppdrag, följer lag och fullgör sina skyldigheter. Vid utövningen av sitt ämbete övervakar JO att de grundläggande fri- och rättigheterna samt de mänskliga rättigheterna tillgodoses. Även Justitiekanslern (JK) har en granskande funktion. JK skall enligt 108 § GL övervaka bland annat myndigheter samt tjänstemän och andra offentligt anställda följer lag och fullgör sina skyldigheter. Vid utövningen av sitt ämbete övervakar JK att de grundläggande fri- och rättigheterna samt de mänskliga rättigheterna tillgodoses. JK och JO och de kan enligt 110 § GL utföra åtal eller förordna att åtal skall väckas.

Bestämmelser om allmänna handlingars offentlighet finns i lagen om offentlighet i myndigheternas verksamhet (21.5.1999/621).

\subsubsection{Danmark}

När det gäller tjänstemännens anställning och ansvar för fel i tjänsten liksom beträffande kontrollen av förvaltningen finns bestämmelser i loven om tjenstemænd i staten, straffeloven, erstatningsansvarsloven, loven om folketingets ombudsman och forvaltningsloven vilka i allt väsentligt överensstämmer med vad som har redovisats för Sverige och Finland. 


\subsubsection{Norge}

När det gäller tjänstemännens anställning och ansvar för fel i tjänsten liksom beträffande kontrollen av förvaltningen finns bestämmelser i tjenestemannsloven, straffeloven, skadeerstatningsloven, sivilombudsmannsloven och offentlighetsloven, vilka i allt väsentligt överensstämmer med vad som har redovisats för Sverige och Finland.

\subsubsection{Island}

När det gäller tjänstemännens anställning och ansvar för fel i tjänsten liksom beträffande kontrollen av förvaltningen finns bestämmelser i lagen om offentligt anställdas rättigheter och förpliktelser, brottsbalken, skadeståndslagen, förvaltningslagen, offentlighetslagen och lagen om Alltingets ombudsman. Bestämmelserna stämmer i allt väsentligt överens med vad som har redovisats för Sverige och Finland.

\subsection{Särskilt om behöriga myndigheter i rambesluten}

\subsubsection{Sverige}

\section{Brottsutredande myndigheter}

För den brottsutredande verksamhet som bedrivs av åklagare och polis finns det i rättegångsbalken och förundersökningskungörelsen särskilda bestämmelser om förundersökning om brott, om användning av tvångsmedel (gripande, beslag, tagande i förvar, husrannsakan och kroppsbesiktning) samt om åtal. Dessa bestämmelser är genom hänvisningar i lagen om straff för smuggling tillämpliga även när brottsutredningar bedrivs av tjänstemän vid tullen eller Kustbevakningen.

Ansvaret för den verksamhet som polisen bedriver ligger hos de regionala polismyndigheterna (en i varje län) med Rikspolisstyrelsen som central förvaltningsmyndighet. Även Rikspolisstyrelsen kan ha till uppgift att leda polisverksamhet. I polisens uppgifter ingår bland annat att bedriva spaning och utredning om brott. Enligt polisförordningen får mer ingripande beslut fattas endast av polismän på viss högre nivå. Detta in- 
nebär att frihetsberövande, tillträde till hus och kroppsvisitation endast får beslutas av polismän på chefsnivå.

En uppgift som Rikspolisstyrelsen har enligt sin instruktion är att vara nationell enhet för Interpol och Europol samt ansvara för den nationella delen av Schengens informationssystem och vara nationell kontaktpunkt för detta informationssystem genom Sirenekontoret. Det är också Rikspolisstyrelsen som är behörig myndighet för utfärdande av en arresteringsorder om utlämning till Sverige från ett annat EU-land för verkställighet av en brottspåföljd som har dömts ut av en svensk domstol. Utfärdandet av arresteringsordern har då föregåtts av en begäran härom från den myndighet som har ansvaret för verkställigheten av den utdömda påföljden (i de flesta fall Kriminalvården).

Tullen har bland annat till uppgift att kontrollera trafiken till och från utlandet så att bestämmelser om in- och utförsel av varor efterlevs. Tullen bedriver inom ramen för sin brottsutredande verksamhet, särskilt i fråga om smugglingsbrott, viss utrednings- och åklagarverksamhet. För den verksamheten har tullen utöver tjänstemän med brottsutredande uppgifter även egna åklagare med begränsade befogenheter att väcka åtal. Beslut om användning av tvångsmedel får fattas endast av en behörig tjänsteman som har genomgått erforderlig utbildning.

Av de rambeslut som ännu inte har genomförts i Sverige är det, av hittillsvarande diskussioner att döma, endast beträffande rambeslutet om en europeisk bevisinhämtningsorder som det kan vara aktuellt att i genomförandelagstiftningen som behörig myndighet utse någon annan brottsutredande myndighet än åklagare.

\section{Myndigheter som har till uppgift att verkställa utdömda brottspåföljder}

Kriminalvården ansvarar för att verkställa sådana av domstol utdömda brottspåföljder som innebär fängelse, skyddstillsyn och samhällstjänst. För påföljder för döms ut för ungdomar och personer med allvarlig psykisk störning ansvarar andra myndigheter (Statens institutionsstyrelse respektive Socialstyrelsen).

Enligt förordningen om överförande från Sverige enligt en europeisk arresteringsorder är Kriminalvården en av de myndigheter som av Rikspolisstyrelsen kan begära att en arresteringsorder skall utfärdas. I dessa fall fattas Kriminalvårdens beslut av tjänstemän vid det nationella huvudkontoret. 
Kronofogdemyndigheten ansvarar för verkställighet av dom eller annan exekutionstitel, som innefattar betalningsskyldighet eller annan förpliktelse, till exempel böter som har dömts ut av domstol, och verkställighet av beslut om kvarstad eller annan liknande säkerhetsåtgärd. För ledningen av dessa verksamhetsområden ansvarar en kronofogde. För en kronofogde gäller i princip samma behörighetskrav som för en domare.

I regeringens proposition om genomförande av rambeslutet om ömsesidigt erkännande på bötesstraff anges Kronofogdemyndigheten som behörig såväl utfärdande som verkställande myndighet.

\subsubsection{Finland}

\section{Brottsutredande myndigheter}

Regler om förundersökning, åtal och användning av tvångsmedel finns i förundersökningslagen, polislagen, lagen om rättegång i brottmål, och tvångsmedelslagen. En förundersökning om brott leds i första hand av polisen. Även gränsbevaknings-, tull- och militärmyndigheterna kan, med begränsade befogenheter, leda en förundersökning.

\section{Myndigheter som har till uppgift att verkställa utdömda brottspåföljder}

Det är enligt fängelselagen brottspåföljdsverket som ansvarar för verkställigheten av fängelsestraff. Även utsökningsmannen deltar i verkställigheten. Brottspåföljdsverkets uppgift är att ge utsökningsmannen ett verkställighetsförordnande.

Enligt $3 \S$ lagen om verkställighet av böter är det rättsregistercentralen som ansvarar för verkställigheten av bötesstraff. I praktiken är det rättsregistercentralens uppgift att skicka en betalningsuppmaning till den bötfällde om den bötfällde inte betalat böterna frivilligt. Om böterna, trots betalningsuppmaning, inte betalas, övergår ansvaret för indrivningen av bötesbeloppet på utsökningsverket. Om verkställigheten sker genom utsökning skall utsökningsbalkens bestämmelser i tillämpliga delar iakttas.

I lagstiftningen om genomförande av rambesluten om ömsesidigt erkännande på bötesstraff och om ömsesidigt erkännande på beslut om förverkande anges Rättsregistercentralen som såväl utfärdande som verkställande myndighet. 


\subsubsection{Danmark}

\section{Brottsutredande myndigheter}

Regler om förundersökning, åtal och tvångsmedel finns i retsplejeloven. Under justitieministern är det Rigsadvokaten, med två särskilda och sex regionala statsadvokater, och Rigspolitichefen, med en centralmyndighet och regionala enheter (politikredser), som har ansvaret för förundersökningar om brott och åtal för brott.

Myndigheter som har till uppgift att verkställa utdömda brottspåföljder Det är Direktoratet för Kriminalforsorgen i Justitsministeriet som ansvarar för verkställigheten av utdömda brottspåföljder när det gäller bland annat fängelse och samhällstjänst.

\subsubsection{Norge}

Brottsutredande myndighet

Regler om förundersökning, åtal och tvångsmedelsanvändning finns i straffprosessloven.

Centralt ledningsorgan för polisen är Justisdepartementet. Departementet har delegerat en stor del av sitt ansvar till sitt polisdirektorat, som handlar under justitieministerns konstitutionella ansvar. När det gäller den egentliga polisverksamheten (i de regionala polisdistrikten) och i administrativa frågor är polisen underställd departementet och direktoratet. Som åtalsmyndighet är polisen underställd statsadvokaten, riksadvokaten och regeringen.

Norge har när det gäller rambeslutet om en europeisk arresteringsorder ett anslutningsavtal med EU, men avtalet är ännu inte ratificerat. I fråga om utlämning och rättsligt samarbete enligt nu gällande konventioner är det Justisdepartementet som enligt genomförandelagstiftningen är behörig rättslig myndighet.

Myndigheter som har till uppgift att verkställa utdömda brottspåföljder För verkställigheten av brottspåföljder, bland annat fängelse och samhällstjänst, utdömda av domstol eller beslutade av åklagare ligger huvudansvaret på Kriminalomsorgsavdelningen i Justisdepartementet. För den- 
na verksamhet finns en central förvaltningsmyndighet (som är underställd Kriminalomsorgsavdelningen) och sex regioner.

För indrivningen av utdömda böter ansvarar Statens innkrevningssentral som är en förvaltningsmyndighet under Finansdepartementet.

\subsubsection{Island}

\section{Brottsutredande myndigheter}

Regler om förundersökning, åtal och tvångsmedelsanvändning finns i straffprocesslagen.

Under justitieministern är det riksåklagaren, distriktsåklagare och regionala polischefer som har ansvaret för förundersökningar om brott och åtal för brott. Justitieministern har behörighet att instruera om att väcka åtal. I sådana fall skall ministern godkänna åtalet och ett överklagande och dessutom instruera riksåklagaren om sakens behandling, inklusive utredningen.

I fråga om utlämning och rättsligt samarbete enligt nu gällande konventioner är det Justitiedepartementet som enligt genom förandelagstiftningen är behörig rättslig myndighet.

Myndigheter som har till uppgift att verkställa utdömda brottspåföljder Det är Kriminalvården, som handlar på justitieministerns ansvar, som ansvarar för verkställigheten av utdömda brottspåföljder när det gäller bl.a. fängelse och samhällstjänst. För indrivningen av utdömda böter ansvarar ett av Justitieministern utsett polisdirektorat. 



\section{Bilaga}

\subsection{Förteckning över aktuella rambeslut}

Här redovisas så långt möjligt vilka myndigheter i Sverige, Finland och Danmark som är aktuella som behöriga myndigheter enligt rambeslut som har antagits eller som förväntas bli antagna inom den närmaste framtiden. För Norge synes utgångspunkten vara att det är det departement som ansvarar för det i rambeslutet ifrågavarande ämnesområdet - vanligen Justisdepartementet - som kommer att anges som behörig myndighet.

2.1.1 Rådets rambeslut 2002/584/RIF av den 13 juni 2002 om en europeisk arresteringsorder och överlämnande mellan medlemsstaterna

\section{Sverige}

Har genomförts; lagen (2003:1156) om överlämnande från Sverige enligt en europeisk arresteringsorder samt förordningarna (2003:1179) om överlämnande från Sverige enligt en europeisk arresteringsorder och (2003:1178) om överlämnande till Sverige enligt en europeisk arresteringsorder.

Utfärdande myndighet: Åklagarmyndigheten (när det gäller överlämnande för lagföring); Rikspolisstyrelsen på begäran av Kriminalvården, Socialstyrelsen och Statens institutionsstyrelse (när det gäller överlämnande för verkställighet av en frihetsberövande påföljd).

Verkställande myndighet: Åklagarmyndigheten (mottagare av arresteringsordern); allmän domstol (beslut om utlämnande). 


\section{Finland}

Har genomförts; lagen om utlämning för brott mellan Finland och de övriga medlemsstaterna i Europeiska unionen (RP 51/207).

Fyra av landets tingsrätter (Helsingfors, Kuopio, Tammerfors och Uleåborg) är behöriga att fatta beslut om utlämning enligt rambeslutet. Beslutet fattas efter framställning av behörig åklagare vid de fyra tingsrätterna.

\section{Danmark}

Har genomförts; lov nr. 433 af 10. juni 2003, om ændring af lov om udlevering af lovovertrædere og lov om udlevering af lovovertrædere til Finland, Island, Norge og Sverige.

Justitsministeriet är behörig myndighet både som utfärdande och verkställande myndighet.

2.1.2 Rådets rambeslut 2003/577/RIF av den 22 juli 2003 om verkställighet $i$ Europeiska unionen av beslut om frysning av egendom eller bevismaterial

\section{Sverige}

Har genomförts; lagen (2005:500) om erkännande och verkställighet inom Europeiska unionen av frysningsbeslut.

Utfärdande myndighet: Åklagarmyndigheten

Verkställande myndighet: Åklagarmyndigheten (med överprövning av domstol)

\section{Finland}

Har genomförts; lagen om verkställighet i Europeiska unionen av frysningsbeslut av egendom eller bevismaterial (RP 56/2007).

Beslut om verkställande av ett frysningsbeslut fattas av häradsåklagare vid fyra tingsrätter (Helsingfors, Kuopio, Tammerfors, Uleåborg). Beslut om översändande av frysningsbeslut från Finland fattas på begäran av behörig åklagare vid de fyra tingsrätterna.

\section{Danmark}

Har genomförts; lov 1434 af 22. december 2004 om fuldbyrdelse af visse strafferetlige afgørelser i Den Europæiske Union. 
Behöriga myndigheter är domstolarna samt anklagemyndigheden, som omfattar Justitsministeriet, Rigsadvokaten, statsadvokaterne och politidirektørerne.

2.1.3 Rådets rambeslut 2005/214/RIF av den 24 februari 2005 om tillämpning av principen om ömsesidigt erkännande på bötesstraff

\section{Sverige}

Har genomförts; lagen (2009:1427) om erkännande och verkställighet av bötesstraff inom Europeiska unionen

Utfärdande och verkställande myndighet: Kronofogdemyndigheten

\section{Finland}

Har genomförts; lagen om det nationella genomförandet av de bestämmelser som hör till området för lagstiftningen i rambeslutet om tillämpning av principen om ömsesidigt erkännande på bötesstraff och om tillämpning av rambeslutet (RP 142/2006).

Behörig myndighet är rättsregistercentralen.

\section{Danmark}

Har genomförts; lov 1434 af 22. december 2004 om fuldbyrdelse af visse strafferetlige afgørelser i Den Europæiske Union.

Justitsministeriet är behörig myndighet både som utfärdande och verkställande myndighet.

2.1.4 Rådets rambeslut 2006/783/RIF av den 6 oktober 2006 om tillämpning av principen om ömsesidigt erkännande på beslut om förverkande

Sverige

Godkänt av riksdagen: Proposition 2004/05:55.

Genomförandelagstiftning: Utredning pågår.

Utfärdande myndighet:Kronofogdemyndigheten

Verkställande myndighet: Kronofogdemyndigheten 


\section{Finland}

Har genomförts; lagen om det nationella genomförandet av de bestämmelser som hör till området för lagstiftningen i rambeslutet om tillämpning av principen om ömsesidigt erkännande på beslut om förverkande och om tillämpning av rambeslutet (RP 47/2007).

Behörig myndighet är rättsregistercentralen.

\section{Danmark}

Har genomförts; lov 1434 af 22. december 2004 om fuldbyrdelse af visse strafferetlige afgørelser i Den Europæiske Union.

Justitsministeriet är behörig myndighet både som utfärdande och verkställande myndighet.

\subsubsection{Rådets rambeslut 2008/909/RIF av den 27 november 2008 om} tillämpning av principen om ömsesidigt erkännande på brottmålsdomar avseende fängelse eller andra frihetsberövande åtgärder $i$ syfte att verkställa dessa inom Europeiska unionen

\section{Sverige}

Godkänt av riksdagen: Proposition 2007/08:84.

Genomförandelagstiftning: Utredning pågår.

Utfärdande och verkställande myndighet: Kriminalvården, Socialstyrelsen, Statens institutionsstyrelse

\section{Finland}

Beredning pågår för genomförande av rambeslutet.

Med största sannolikhet kommer de behöriga myndigheterna att vara brottspåföljdsverket och justitieministeriet.

\section{Danmark}

Har genomförts; lov nr. 347 af 14. maj 2008 om ændring af lov om fuldbyrdelse af visse strafferetlige afgørelser i Den Europæiske Union, lov om udlevering af lovovertrædere og lov om Det Centrale Dna-profilregister (Gennemførelse af rammeafgørelsen om en europæisk bevissikringskendelse med henblik på fremskaffelse af genstande, dokumenter og data til brug i straffesager [RA 2008/978] og rammeafgørelsen om anvendelse af princippet om gensidig anerkendelse på domme i straffesager 
om idømmelse af frihedsstraffe eller frihedsberøvende foranstaltninger med henblik på fuldbyrdelse i Den Europæiske Union [RA 2008/909]; loven er ikke trådt i kraft)

Behöriga myndigheter är domstolarna, samt anklagemyndigheden, som omfattar Justitsministeriet, Rigsadvokaten, statsadvokaterne och politidirektørerne.

2.1.6 Rådets rambeslut 2008/947/RIF av den 27 november 2008 om tillämpning av principen om ömsesidigt erkännande på domar och övervakningsbeslut i syfte att övervaka alternativa påföljder och övervakningsåtgärder

Sverige

Godkänt av riksdagen: Proposition 2008/09:19.

Genomförandelagstiftning: Utredning pågår.

Utfärdande och verkställande myndighet: Kriminalvården

\section{Finland}

Beredning pågår för genomförande av rambeslutet.

Med största sannolikhet kommer de behöriga myndigheterna att vara brottspåföljdsverket och justitieministeriet.

\section{Danmark}

Arbete med genomförande av rambeslutet pågår; folketinget har den 27 maj 2008 antagit folketingsbelutning nr. B 78 om udkast til rammeafgørelse om anerkendelse af og tilsyn med betingede straffe, alternative sanktioner og betingede domme, med henblik på ophævelse af det parlamentariske forbehold.

2.1.7 Rådets rambeslut 2008/978/RIF av den 18 december 2008 om en europeisk bevisinhämtningsorder att inhämta föremål, handlingar eller uppgifter som ska användas i straffrättsliga förfaranden

Sverige

Godkänt av riksdagen: Proposition 2007/08:141.

Genomförandelagstiftning: Utredning pågår. 
Utfärdande och verkställande myndighet: Åklagarmyndigheten eller annan brottsutredande myndighet/allmän domstol

\section{Finland}

Arbete pågår för genomförande av rambeslutet.

\section{Danmark}

Har genomförts; se ovan under 5).

\subsubsection{Rådets rambeslut 2009/299/RIF om verkställighet av utevarodomar}

\section{Sverige}

Godkännande av riksdagen: Proposition 2008/09:20.

Genomförandelagstiftning:

\section{Finland}

Rambeslutet påverkar inte de behöriga myndigheter som utsetts enligt berörda tidigare rambeslut.

\section{Danmark}

Arbete med genomförande av rambeslutet pågår; folketinget har den 18 december 2008 antagit folketingsbelutning nr. B 8 om udkast til rammeafgørelse om fremme af anvendelsen af princippet om gensidig anerkendelse i forbindelse med afgørelser afsagt, uden at den pågældende selv var til stede under retssagen, og om ændring af en række rammeafgørelser, med henblik på ophævelse af det parlamentariske forbehold.

2.1.9 Rådets rambeslut 2009/829/RIF om tillämpning av principen om ömsesidigt erkännande av beslut om övervakningsåtgärder för brottsmisstänkta

\section{Sverige}

Godkänt av riksdagen: Proposition 2008/09:192.

Genomförandelagstiftning:

Utfärdande och verkställande myndighet: Åklagarmyndigheten 
Finland

Arbete med genomförande av rambeslutet har ännu inte inletts.

Danmark

Arbete pågår för genomförande av rambeslutet. 